\title{
The Status of Women in a Socialist Order: Czechoslovakia, 1948-1978
}

\begin{abstract}
All citizens shall have equal rights and equal duties. Men and women shall have equal status in the family, at work and in public activity. The society of the working people shall ensure the equality of all citizens by creating equal possibilities and equal opportunities in all fields of public life.
\end{abstract}

ČSSR CONSTITUTION, ARTICLE 20

When we Communist women protested against the disbanding of the women's organization, we were informed that we had equality. That we were equal, happy, joyful, and content, and that, therefore, our problem was solved.

WOMAN DELEGate to THE PRAGUe CONFERENCE OF DISTRICT PARTY OFFICIALS, MAY 1968

When Communist elites came to power in Czechoslovakia at the end of the Second World War, they attempted to create a new social and political order. As part of this process, efforts were made to improve the status of women and to incorporate them as full participants in a socialist society. Guided by Marxist-Leninist ideology and Soviet experience, Czech and Slovak leaders proclaimed their commitment to female equality and enacted a constitution which guaranteed women equal rights in all areas of life. These guarantees were supplemented by a variety of legal and administrative measures prohibiting discrimination against women in employment and affirming the state's responsibility to assist women in performing their maternal functions. ${ }^{1}$

In this paper, I shall examine the influence of these guarantees on women's roles in four areas of life (education, employment, politics, and the family) in order to answer three basic questions: (1) What impact have the institutional arrangements and ideological commitments associated with current socialist states had on women's status? Has the institution of a socialist system led to female equality in Czechoslovakia? (2) How are changes in certain areas of women's lives related to others? Do increased access to education and labor force participation lead to higher levels of political participation or changes in roles within the home? (3) How do we account for continued inequality in certain areas of life?

I began from the hypothesis that the institution of a new political system would be conducive to female equality in Czechoslovakia for two reasons. First, the political elites in Czechoslovakia, like those in other Communist states, adhere to an ideology which explicitly supports female emancipation. In addition, Communist elites, because of their control over the means of socialization-including the schools and mass media - and their ability to manipulate social and

1. See Senta Radvanová et al., Žena a právo (Prague, 1971) for a review of legal measures concerning women.

I would like to express my appreciation to the International Research and Exchanges Board, which made possible much of the research on which this article is based. 
Table 1. Women as a Proportion of Full-time Students in Higher Education (in percent)

\begin{tabular}{lccc}
\hline Year & Czechoslovakia & Czech Lands & Slovakia \\
\hline 1945 & 18.5 & 18.5 & 18.7 \\
1950 & 22.4 & 23.1 & 19.5 \\
1955 & 25.3 & 26.4 & 22.8 \\
1960 & 37.1 & 36.3 & 38.9 \\
1965 & 40.7 & 40.3 & 41.5 \\
1970 & 40.2 & 38.1 & 43.5 \\
1975 & 41.0 & 38.3 & 42.9 \\
\hline
\end{tabular}

Sources: Statistická ročenka republiky Ceskoslovenské, 1958-59 (Prague, 1958 and 1959); and Statistická ročenka CSSR, 1960-76 (Prague, 1960-76).

economic policy, appear to have a greater capacity to achieve their goals than elites in other political systems. Both elite intent and capacity seem to be more favorable to female equality in socialist states.

The outlook for such equality seemed particularly bright in Czechoslovakia, because prewar conditions created a more favorable starting point for post-World War II efforts to change women's roles. I expected women's status to be better in Czechoslovakia than in other Communist states, because many of the obstacles to change in women's roles were less severe. A relatively developed country before the Communists came to power, Czechoslovakia also had widespread female, as well as general, literacy and lacked a religious tradition which markedly subordinated women. Many of the legal barriers to women's equality had been removed during the interwar period, and Czech and Slovak women had a long tradition of participation in social, cultural, and political life.

I also hypothesized that changes in women's status in certain areas of life, such as education and employment, would be reflected in corresponding changes in political and family roles. The former expectation was drawn from the literature concerning the determinants of political participation in Western and socialist societies, while the latter derived from the Marxist expectation that changes in women's economic status would lead to a more equal division of labor within the home.

As the words of the woman party official quoted above indicate, the institution of a socialist system has not led to equality for women in Czechoslovakia. Nor is the status of women significantly better in this country than in other, less-developed socialist states. Both the extent to which women have achieved equality and the pattern of changes in women's roles display a fairly regular trend in all of the states in the area. ${ }^{2}$ I shall analyze these changes in more detail in the first section of this paper. In the second section, I shall advance some explanations for the continued inequality of women in Czechoslovakia and argue that the uneven pattern of change in women's roles reflects differential elite commitment to promoting change in various areas of life.

2. For a comparison of women's status in Eastern and Western Europe, see Sharon Wolchik, "Politics, Ideology, and Equality: The Status of Women in Eastern Europe" (Ph.D. diss., University of Michigan, 1978). 
Table 2. Women as a Percentage of Secondary Students, by Type of Education, Czechoslovakia, 1950-70 (in percent)

\begin{tabular}{lcccc}
\hline Year & Total & General & Vocational & Teacher Training \\
\hline $1950^{\mathrm{a}}$ & 42 & 37 & 45 & \\
1955 & 51 & 54 & 44 & 89 \\
1960 & 55 & 64 & 48 & 95 \\
1965 & 59 & 66 & 54 & 98 \\
1970 & 61 & 65 & 58 & 97 \\
\hline
\end{tabular}

a Vocational and teacher training combined.

Sources: UNESCO Statistical Yearbook, 1965, 1971, and 1972 (Paris, 1965, 1971, 1972).

Changes in women's roles in Czechoslovakia and in other socialist states have been greatest in the areas of educational access and employment. Educational opportunities for women have increased dramatically since World War II. Women currently comprise approximately 60 percent of secondary school students and slightly over 40 percent of all students in higher education (see tables 1 and 2). By contrast, in 1935, approximately 35 percent of all general secondary students and 15 percent of all students in higher education were women. ${ }^{3}$ In part, the increase in access to education for women reflects the emphasis the new elites placed on increasing educational opportunities for the population as a whole. The magnitude of this increase is reflected by the enrollment ratio (total number of students as a proportion of population of school age) which, at the secondary level, rose from an average of fifteen from 1947 to 1949 to thirty-nine in $1972 .{ }^{4}$ The number of students in higher education also increased substantially, from an average of two hundred per one hundred thousand inhabitants between 1930 and 1934 to nine hundred eighty (total students) or seven hundred ninety (full-time students) in 1974. ${ }^{\circ}$

As the steady increase in the proportion of women students indicates, women's access to education has increased more rapidly than that of the population as a whole. The increase in female students has been particularly noticeable in Slovakia. Whereas the number of women students in higher education approximately doubled in the Czech Lands from 1945 to 1975, the number of women students in Slovakia in 1975 was over eleven times greater than in 1945. The large relative increase in women students in Slovakia can be explained by the small absolute number of female students in $1945 .^{\circ}$

3. Ceskoslovenské Ministerstvo zahraníčních věci, Informační odděleni, Statistická príručka republiky Ceskoslovenské, 1940 (London, 1940), table 72.

4. UNESCO, World Survey of Education, 5 vols. (Paris, 1955-71), 3:392; and UNESCO Statistical Yearbook, 1974 (Paris, 1974), p. 148.

5. Statisticheskii ezhegodnik stran-chlenov Soveta ekonomicheskoi vzaimopomoshchi, 1970 (Moscow, 1970), p. 408; and Statisticheskii ezhegodnik stran-chlenov Soveta ekonomicheskoi vzaimopomoshchi, 1975 (Moscow, 1975), p. 416.

6. The number of women students increased from 1,618 to 20,374 in Slovakia between 1945 and 1975. In the Czech Lands, women students increased from 8,530 in 1945 to 28,553 in 1975 (see Statistická ročenka republiky Ceskoslovenské [Prague, 1958], and Statistická ročenka CSSR, 1958 and 1976). The near equalization of educational opportunities for women is also evident in the enrollment ratios for men and women at both levels. Whereas this ratio was 34 for women compared to 36 for the total population of secondary school age in 1960, by 1972, women's enrollment ratio (47) exceeded that of the population as a whole (39). Men's enrollment ratio continues to exceed women's in higher education, but the difference is decreasing (see UNESCO Statistical Yearbook, 1974, p. 148). 
Table 3. Women in the Labor Force, 1948-75 (in thousands or percent)

\begin{tabular}{c|ccc|ccc|ccc}
\hline & \multicolumn{2}{|c|}{ CZECHOSLOVAKIA } & \multicolumn{2}{c|}{ CZECH LANDS } & \multicolumn{3}{c}{ SLOVAKIA } \\
\hline $\begin{array}{c}\text { Year } \\
(1)\end{array}$ & $\begin{array}{c}\text { Women } \\
(2)\end{array}$ & $\begin{array}{c}\text { Total } \\
(3)\end{array}$ & $\begin{array}{c}\text { Percent } \\
(2) \div(3) \\
(4)\end{array}$ & \begin{tabular}{rl|cc|ccc} 
Women \\
$(5)$
\end{tabular} & $\begin{array}{c}\text { Total } \\
(6)\end{array}$ & $\begin{array}{c}\text { Percent } \\
(5) \div(6) \\
(7)\end{array}$ & $\begin{array}{c}\text { Women } \\
(8)\end{array}$ & $\begin{array}{c}\text { Total } \\
(9)\end{array}$ & $\begin{array}{c}\text { Percent } \\
(1) \div(9)\end{array}$ \\
\hline 1948 & 2,098 & 5,545 & 37.8 & 1,485 & 4,019 & 36.9 & 613 & 1,526 & 40.1 \\
1955 & 2,553 & 5,998 & 42.6 & 1,849 & 4,342 & 42.6 & 704 & 1,656 & 42.5 \\
1960 & 2,608 & 6,098 & 42,8 & 1,994 & 4,530 & 44.0 & 614 & 1,568 & 39.2 \\
1965 & 2,917 & 6,515 & 44.8 & 2,214 & 4,787 & 46.3 & 703 & 1,728 & 40.7 \\
1970 & 3,286 & 7,034 & 46.7 & 2,402 & 5,026 & 47.8 & 884 & 2,008 & 44.0 \\
1971 & 3,346 & 7,119 & 47.0 & 2,434 & 5,081 & 47.9 & 912 & 2,038 & 44.7 \\
1972 & 3,400 & 7,174 & 47.4 & 2,468 & 5,111 & 48.3 & 932 & 2,063 & 45.2 \\
1973 & 3,463 & 7,282 & 47.6 & 2,505 & 5,166 & 48.5 & 958 & 2,116 & 45.3 \\
1974 & 3,527 & 7,376 & 47.8 & 2,529 & 5,207 & 48.6 & 998 & 2,169 & 46.0 \\
1975 & 3,565 & 7,432 & 48.0 & 2,541 & 5,219 & 48.7 & 1,024 & 2,213 & 46.3 \\
\hline
\end{tabular}

Sources: Statistická ročenka republiky Ceskoslovenské, 1958-59; and Statistická ročenka CSSR, 1960-75.

The impact of improved educational opportunities for women is evident in the educational attainment of both sexes, particularly among the younger age groups. While the educational levels of women in the total population remain somewhat lower than those of men, the educational levels of women in the 20-24 age group exceed those of men. Thus, in 1961, 20.5 percent of all women and 19.2 percent of all men between the ages of 20 and 24 had completed some form of secondary education. By 1970, 33.9 percent of all women, compared to 20.5 percent of all men, had completed secondary school. Similar differences are evident in higher education. Whereas .5 percent of women in this age group, compared with 1.2 percent of men, had completed higher education in 1961, by 1970 , the proportion was reversed ( 1.3 percent women, and .9 percent men).$^{7}$

The post-World War II period has also seen a considerable increase in women's participation in the labor force in Czechoslovakia. Women's proportion of the total labor force increased from 37.8 percent in 1948 to 48 percent in 1975 (see table 3). This proportion is one of the highest in Eastern Europe and considerably higher than in the Western countries. ${ }^{8}$ The extent to which female employment has become an accepted part of life in Czechoslovakia is perhaps

7. Figures have been taken from information in "Le developpement de l'instruction scolaire et son influence sur la situation des femmes en Tchecoslovaquie," unpublished manuscript, table 2. In 1961, 15.5 percent of all men and 12.1 percent of all women 25 years of age and older had completed secondary education, while 4.1 percent of all men, compared to .9 percent of all women, had completed higher education. By 1970, slightly over one-half of all men, compared with approximately one-fourth of all women, had finished secondary schooling; 6.3 percent of all men and 2.1 percent of all women 25 years of age and older had completed higher education (from information in UNESCO Statistical Yearbook, 1965 [Paris, 1965], pp. 418-19; and UNESCO Statistical Yearbook, 1974, p. 70).

8. Women comprised a higher proportion of the total labor force in 1974 only in the USSR ( 51 percent) and in East Germany (50 percent). Women's proportion of the labor force in the West ranged from approximately 38 percent in the United States and Austria to a low of 19 percent in Greece in 1970. 
better illustrated by the proportion of all women in the productive ages (15 to 54) who are employed outside the home. This proportion was 71 percent in 1962 , and by $1970,84.3$ percent of all women in this age group were employed. ${ }^{9}$

These figures reflect the success of Communist elites in encouraging women to enter the labor force. As in other East European countries, the adoption of ambitious industrialization plans based on a labor intensive strategy of economic development required the use of all available labor resources. Economic necessity coincided with the Marxist-Leninist emphasis on women's participation in production as the precondition for female emancipation. A variety of moral and financial incentives was used to encourage women to enter the labor force. Chief among these were wage structures which necessitated two incomes for most households. In the immediate postwar period, employed women were also given preferential access to scarce and rationed goods. ${ }^{10}$ The regime's reliance on women's labor is reflected in the fact that women accounted for approximately 80 percent of the total increase in the labor force from 1948 to 1975.

Clearly, the institution of a socialist system has led to near equality of educational opportunity for women and a marked expansion in the number of women who are economically active outside the home. However, it has not led to the elimination of differences between the sexes in either of these areas. As tables 2 and 4 indicate, the types of education men and women receive continue to differ considerably. At the secondary level, girls continue to comprise the largest proportion of students in both general education and teacher training programs. The number of girls in vocational education hà increased as well, but girls who choose this type of education continue to specialize in traditional female areas. ${ }^{11}$

The pattern is similar in higher education. Women continue to be concentrated in such traditionally feminine branches of learning as the humanities and education, as well as in medicine and the social sciences, areas which have become feminized since World War II (see table 4). The proportion of women students in engineering schools has increased somewhat (from 10.8 percent in 1956 to 14.6 percent in 1971 ), but women continue to be underrepresented in this field in relation to their share of total students. A similar situation exists at agriculture schools. The sex-related differences in educational specialization contribute to persistent differences between men and women in the labor force.

As in the case of education, the influx of women into the labor force has not led to the decline of traditional conceptions of proper roles for men and women in the work place. Despite the increase in the number of employed women, women continue to be segregated in certain types of occupations and to earn less than men. They are seldom found in decision-making roles in the economy.

9. Ernest Magdolen, Spôsob života zamestnaných žien v mimopracovnom čase (Bratislava, 1973), p. 25.

10. For examples of appeals made to women to join the labor force, see "Priprava mezinárodního dne žen," Radkyne žen, 1949, no. 2, p. 20; and B. Skrlantová, "Veliká sila," Radkyne žen, 1949, no. 3, pp. 34-35.

11. Stefan Hora, $Z a$ vyššiu účast zamestnaných žien v riadiacej činnosti (Bratislava, 1972 ), notes that, although girls comprise nearly half of all students in specialized vocational education, they account for only one-third of students in industrial specializations. 
Table 4. Women as a Percentage of Full-time Students in Higher Education, by Field of Study, Czechoslovakia, 1956-70

\begin{tabular}{|c|c|c|c|c|c|c|c|c|c|c|}
\hline & Total & Humanities & Education & Fine Arts & Law & $\begin{array}{c}\text { Social } \\
\text { Sciences }\end{array}$ & $\begin{array}{l}\text { Natural } \\
\text { Sciences }\end{array}$ & Engineering & Medicine & Agriculture \\
\hline 1956 & 28.7 & 52.9 & 53.5 & 29.9 & 22.4 & 15.7 & 27.8 & 10.8 & 49.0 & 15.1 \\
\hline 1960 & 34.1 & 43.2 & 62.2 & 30.5 & 28.4 & 28.4 & 49.4 & 11.8 & 55.5 & 18.9 \\
\hline 1962 & 36.3 & 48.1 & 66.9 & 31.5 & 33.2 & 31.0 & 33.4 & 13.0 & 59.8 & 21.0 \\
\hline 1963 & 37.4 & 43.7 & 68.2 & 34.3 & 34.9 & 33.7 & 39.4 & 14.1 & 62.1 & 22.7 \\
\hline 1965 & 38.2 & 66.9 & 48.9 & 37.9 & 54.9 & 53.2 & 65.4 & 14.3 & 62.5 & 26.0 \\
\hline 1966 & 39.2 & 61.1 & 72.0 & 34.2 & 55.5 & 49.3 & 53.8 & 17.9 & 62.7 & 26.9 \\
\hline 1967 & 39.9 & 64.0 & 72.0 & 34.2 & 50.4 & 46.9 & 52.5 & 23.9 & 61.0 & 27.5 \\
\hline 1968 & 39.7 & 64.0 & 71.3 & 34.0 & 53.0 & 46.0 & 49.9 & 16.8 & 59.1 & 26.8 \\
\hline 1969 & 38.0 & 29.8 & 75.5 & 33.6 & 37.3 & 45.9 & 32.8 & 14.8 & 57.6 & 25.3 \\
\hline 1970 & 37.9 & 59.1 & 74.5 & 33.6 & 38.6 & 43.9 & 46.2 & 14.7 & 56.2 & 25.5 \\
\hline
\end{tabular}

Sources: UNESCO Statistical Yearbook, 1964-74 (Paris, 1964-74), tables of distribution of students by field of study. 
Table 5. Average Monthly Wages of Men and Women Employed in the National Economy, Socialist Sector Only, Czechoslovakia, 1959-70 (in Czechoslovak crowns)

\begin{tabular}{lccc}
\hline & Men & Women & Women's Wages as \% of Men's \\
\hline 1959 & 1,598 & 1,057 & 66.1 \\
1964 & 1,781 & 1,196 & 67.2 \\
1966 & 1,877 & 1,232 & 65.7 \\
1968 & 2,105 & 1,400 & 66.6 \\
1970 & 2,336 & 1,565 & 67.0 \\
\hline
\end{tabular}

Source: Alena Heitlinger, "Women's Labour Participation in Czechoslovakia Since World War II," paper presented at the symposium on "The Working Sexes," at the University of British Columbia, October 15-16, 1976.

Women employed in the socialist sector of the national economy in Czechoslovakia earn approximately two-thirds of the wages that men earn (see table 5). Differences between the average wages of the sexes have remained fairly constant throughout the post-World War II period and are only slightly lower than wage differentials during the interwar period. ${ }^{12}$ Comparison of the proportion of men and women in particular wage categories illustrates the persistence of sex-related differences in income. In 1966, over 70 percent of all women employed in the socialist sector of the national economy, compared with 15 percent of all men, were in the two lowest wage categories, while less than 3 percent of all women and over 30 percent of all men were in the top two categories. The differences between the sexes were virtually the same at the lower end of the scale in 1970, when approximately 6 percent of all men and 45 percent of all women were in the two lowest wage categories. Sex differences at the upper end of the wage scales decreased somewhat, but men were four times more likely than women to be in the top two categories (65 percent of all men, compared to 15 percent of all women)..$^{13}$

The persistence of sex-related differences in income, despite constitutional guarantees of equal pay for equal work, is attributable to several factors. In part, these differences occur because women are concentrated in certain lowpriority branches of the economy. As table 6 indicates, women comprise a far larger proportion of the labor force in health and social services, education, and trade and public catering than in construction, transportation, and science and research, all fields with high average wages. A 1965 study indicates that wages in branches of the economy in which women predominated ranged from 1,000 to $1,200 \mathrm{Kčs}$., while those in which they were less commonly employed had average wages of over $2,000 \mathrm{Kčs} .{ }^{14}$

Differences between men's and women's wages also persist within the various branches of the economy. In 1963, for example, women's wages were 65 percent those of men in construction and 62.3 percent of men's in industry. Sexrelated differences in wages were approximately the same in heavily feminized

12. Between 1929 and 1935 , average daily wages of women decreased steadily but slightly from 62.3 percent to 59.3 percent (see Organisačni zpravodaj československého svazu žen, vol. 2 [1952], p. 85).

13. Jiři Fremr, "Rozdily ve mzdách mužů a žen," Statistika, 11 (1965): 506.

14. Ibid. 
Table 6. Women in the Labor Force, by Branch of Employment, Czechoslovakia, 1951-74 (in percent)

\begin{tabular}{lrrrrrr}
\hline & 1951 & 1955 & 1960 & 1965 & 1970 & 1974 \\
\hline Industry & 33.2 & 34.9 & 37.7 & 41.1 & 43.9 & 44.7 \\
Construction & 8.1 & 10.0 & 12.3 & 14.0 & 15.3 & 16.6 \\
Agriculture & 54.1 & 55.0 & 52.6 & 51.2 & 49.9 & 47.4 \\
Transportation & 15.0 & 14.4 & 15.6 & 19.4 & 22.6 & 24.0 \\
Communication & 37.6 & 44.7 & 50.7 & 58.1 & 64.0 & 65.7 \\
Supply & $\ldots$. & 42.7 & 46.2 & 46.2 & 50.8 & 51.6 \\
Trade and Catering & 63.4 & 61.9 & 68.3 & 71.6 & 74.5 & 75.5 \\
Science and Research & $\ldots$. & 23.6 & 31.0 & 31.4 & 33.7 & 36.2 \\
Communal Services & $\ldots$. & 44.4 & 46.5 & 54.2 & 53.5 & 55.8 \\
Housing Economy & $\ldots$. & 65.2 & 65.3 & 54.4 & 51.6 & 51.9 \\
Health and Social Care & 71.2 & 72.1 & 73.5 & 77.5 & 79.1 & 80.4 \\
Education, Culture, and & & & & & & \\
$\quad$ Physical Education & 56.6 & 55.9 & 59.7 & 61.0 & 64.2 & 67.7 \\
Justice and Information & $\ldots$. & 37.4 & 42.6 & 44.6 & 51.3 & 54.7 \\
Banking and Insurance & $\ldots$. & 45.1 & 54.2 & 61.6 & 67.4 & 70.6 \\
Total & 41.3 & 42.7 & 42.8 & 44.8 & 46.7 & 47.8 \\
\hline
\end{tabular}

Sources: From information in Statistická ročenka republiky Ceskoslovenské, 1958-59; and Statistická ročenka CSSR, 1960-76.

branches of the economy, such as education and culture (in which women's wages were 70.3 percent those of men), health and social services (61.6 percent), and public catering ( 74.9 percent). Differences in men's and women's wages within branches were nearly identical in $1970 .^{15}$

Lower wages for women within branches may be traced to several factors. Despite the rise in women's education and qualification levels, many women do not possess the qualifications required to perform skilled work. The lack of appropriate qualifications is especially acute among older women who entered the labor force directly from their homes. The concentration of female students in general education at the secondary level perpetuates this problem. Only 40 percent of secondary general school graduates are accepted for further study. Those graduates who are not accepted-a disproportionate share of whom are girls-then enter the labor force without useful skills. ${ }^{16}$

Differences in the types of education men and women receive are also evident in the distribution of specialists employed in the national economy. Although women form a substantial proportion of total specialists with secondary or higher education, the majority of women specialists are employed in the areas of administration, health, or education. In 1963, for example, women comprised 23.6 percent of all specialists with higher education employed in the socialist sector of the national economy. However, approximately 27 percent of the women specialists were employed in health services and 51.7 percent in education, culture, and art. These two areas accounted for nearly 80 percent of all women specialists. Male specialists, by contrast, were far less concentrated in these branches ( 35 percent) and far more frequently employed in technical fields and construction ( 36.5 percent of all male specialists), areas in which only 8.7 percent

15. Ibid., p. 504; and Magdolen, Spôsob života, p. 78.

16. Hora, Za vyššiu účast, pp. 8-9. 
of all women specialists were employed. The pattern is similar for men and women with secondary school specializations. ${ }^{17}$

The effects of educational and occupational segregation on women's wages are compounded by the fact that women often hold jobs which do not fully utilize their qualifications. The 1970 list of experts indicates that 43 percent of women with completed secondary education were employed in positions which required the qualifications they possessed, and approximately 3 percent were in positions which officially required higher qualifications. However, over 54 percent were in categories requiring lower qualifications than they had. By contrast, 53 percent of men with equivalent education were classified in categories corresponding to their qualifications, while 22 percent were in categories which required higher qualifications than they possessed. ${ }^{18}$ Thus, the underutilization of women's skills also contributes to keeping women's wages at lower levels.

Persisting inequality of women in the sphere of work is also evident in their minimal representation in leadership positions. Despite the rise in educational levels of women and their increasing proportion of the total labor force, women continue to hold approximately 5 percent of all leading positions in the economy. ${ }^{19}$ While women are better represented in leadership positions in those areas in which they predominate, their share of such positions is still minimal. ${ }^{20}$

The small number of women leaders in part reflects women's reluctance to accept responsible positions. In a study conducted in forty-two enterprises in four branches of the economy in the early 1970s, Slovak researchers found that women were less willing than men to accept leadership positions. They also tended to be interested in lower level functions, while most men aspired to middle or top level positions. ${ }^{21}$ The paucity of women in such positions is also influenced by top leaders' unwillingness to nominate women for leadership positions and by the reluctance of both men and women to work under women supervisors. Approximately 72 percent of the men interviewed and 44 percent of the women preferred to work under male supervisors. Less than 3 percent of the men and under 10 percent of the women preferred a woman leader. ${ }^{22}$

17. Figures have been taken from information in Fremr, "Rozdíly," pp. 507-8; and Hora, Za vyššiu úćast, p. 7.

18. Hora, Za vyššiu účast, pp. 8-9; Vladimír Wynnczyk, "Venkovská žena součastnosti, 1967," Zprávy státni populačni komise, 1969, no. 5, p. 17.

19. Jaroslava Bauerová, "Rodinná problematika vedoucích pracovnic," Sociologický casopis, 5 , no. 5 (1970): 450 .

20. For information concerning the decreasing representation of women among heads of schools from the one-room rural level to urban high schools, see M. Mrkosová's report on research on the social positions of teachers (reported in Eva Bártová, "Žena a rodina $\mathbf{v}$ zrcadle společenského výzkumu v CSSR," Sociologický časopis, 9, no. 2 [1973]: 209). Stefan Hora's research indicates that 9 percent of women, compared with 25 percent of men, employed in four branches of the national economy held leading functions. Every eighth male in the sample, compared with every twenty-sixth female held one of the three top functions in an organization (see Hora, $Z a$ vyššiu účast, p. 15). For a review of studies dealing with women's leadership roles in medicine and other branches of the economy, see Alena Heitlinger, "Women's Labour Participation in Czechoslovakia Since World War II," paper presented to the symposium on "The Working Sexes," University of British Columbia, October $15-16,1976$, pp. 11-13.

21. Hora, $Z a$ vyššiu účast, p. 15.

22. Ibid., p. 19. Similar differences in attitudes toward desired and expected equality for women in a number of areas are reported in Eva Bártová, "Postoje $k$ problému ženy a rodiny," Sociologický ćasopis, 8, no. 1 (1972) : 44-61. 
In sum, women receive better education and are more likely to work outside the home in Czechoslovakia since the institution of the new socialist system. However, these changes have not resulted in true equality in the type of education men and women receive or in the distribution of wages or decisionmaking roles in the economy. Nor have they led to corresponding changes in women's political participation or roles in the home.

Although it might be expected that improvement in women's educational levels and their greater involvement in work outside the home would be reflected in an increase in their political activity, in fact, women continue to be excluded from the exercise of political power in Czechoslovakia. Studies of the political behavior of women in other societies indicate that women have less interest in and information about politics and a lower sense of political efficacy. They are also less involved in politics at all levels. Moreover, women's political activity conforms to what has been termed the "law of increasing disproportion" evident for members of other disadvantaged groups, that is, the activity of women and their numerical representation decrease as the demands and importance of the activity or office increase. ${ }^{23}$

The available information concerning political behavior at the mass level in Czechoslovakia indicates that women's interest in politics and political activity is not great. A survey of women's attitudes concerning employment and their families conducted in the early 1970s indicates that 20 percent of all women and 36 percent of unemployed women who were interviewed claimed to have no interest whatsoever in political questions. ${ }^{24}$ Although lack of comparable information for the level of political interest of men makes it difficult to judge these responses, time-budget studies indicate that women spend less time on public activities than do men. ${ }^{25}$ They are also less active in political activities in the factory, ${ }^{28}$ and are less frequently members of the Communist Party. The proportion of female party members was highest in 1949 (33 percent), when the merger of the Communist and Social Democratic parties and recruiting campaigns aimed specifically at women brought large numbers of new women recruits into the party. They have accounted for approximately 27 percent of party members throughout the $1950 \mathrm{~s}$ and $1960 \mathrm{~s},{ }^{27}$ a proportion which has remained stable despite the elite's efforts to encourage more women to join the party.

At the elite level, the political behavior of women in Czechoslovakia also resembles that of women in other societies. As in Western countries, women's representation in elite bodies is inversely related to the importance of the office.

23. For references to studies which illustrate these tendencies, see Lester W. Milbrath, Political Participation (Chicago, 1969), pp. 54-58; and M. Kent Jennings and Norman Thomas, "Men and Women in Party Elites: Social Roles and Political Resources," Midwest Journal of Political Science, 12, no. 4 (November 1968): 470.

24. Magdolen, Spôsob života, pp. 65-66 and appendix, table 1.

25. Ibid., appendix, table 1.

26. Dragoslav Slejska, "Problémy aktivity žen pri účasti na řizení $\mathrm{v}$ průmyslovém závodu," Sociologický časopis, 1, no. 5 (1965): 511-21.

27. R. V. Burks, The Dynamics of Communism in Eastern Europe (Princeton, 1961), p. 68; Barbara Jancar, Czechoslovakia and the Absolute Monopoly of Power (New York, 1971), p. 36. 
Table 7. Women Deputies in the Czechoslovak National Assembly (in percent)

\begin{tabular}{lc}
\hline Years & Percent \\
\hline $1948-49$ & 7.1 \\
$1950-53$ & 10.3 \\
$1954-59$ & 18.0 \\
$1960-63$ & 19.4 \\
$1964-70$ & 20.0 \\
$1971-75$ & 25.7 \\
$1976-79$ & 28.6 \\
\hline
\end{tabular}

Sources: Encyklopedie moderni ženy (Prague, 1966), p. 567; Rudé právo, December 1, 1971, p. 3, and November 9, 1976, p. 4.

Women who become members of the political elite perform functions which resemble traditional female roles and seldom rise to top leadership positions. ${ }^{28}$

The extent to which women's representation in political elites in Czechoslovakia follows the law of increasing disproportion is illustrated by several trends. First, they are better represented in the symbolic, or government, elites at all levels than in the effective, or party, elites. Second, their representation in both elites decreases as we move from the local level to the national level. Finally, they are better represented in the deliberative than in the executive bodies of each elite at all levels.

Women are fairly well represented in the government elite in Czechoslovakia. While Czechoslovakia has not had a female head of state, a woman usually holds one of the deputy chairmanships of the national Assembly, and the number of female national legislators has increased significantly in the past thirty years (see table 7). As in Western countries, they have generally been better represented in government elites at the regional and local levels, although the proportion of women does not vary strictly by level. In 1971, for example, women comprised 31.1 percent of members of regional national committees, 30 percent of district conmittees, and 21.7-28.7 percent of local national committees. ${ }^{29}$

Once they are in the government elite, women also engage in activities which resemble those of their Western counterparts. In 1964, for example, women comprised nearly 60 percent of the National Assembly's committees for food industries, consumer goods, services, trade and communication, and they were overrepresented in relation to their total number of deputies on the committees which dealt with health and culture. In contrast, they comprised 4.2 percent of the membership of the committee for the budget, 6.3 percent of the committee for heavy industry and transport, and less than their total proportion of

28. See Martin Gruberg, Women in American Politics (Oshkosh, Wisc., 1968), pp. 14, 210-18; Maurice Duverger, The Political Role of Women (Paris, 1955), pp. 76 and 86; Elena Haavio-Mannila, "Sex Role Attitudes in Finland, 1966-1970," Journal of Social Issues, 28, no. 2 (1972): 96; and Edmond Dahlstrom, The Changing Roles of Men and Women (Boston, 1971), pp. 300-301. For evidence of specialization of activity, see Duverger, Political Role of Women, pp. 95-98. Irene Diamond, Sex Roles in the State House (New Haven, Conn., 1977) and Jeane J. Kirkpatrick, Political Woman (New York, 1974) discuss similar trends among women state legislators in the United States.

29. Národni výbory, 1971, no. 37, p. 5; Jaroslav Chovanec, Zastupitelská soustava Ceskoslovenské socialistické republiky (Prague, 1974), pp. 130-31. 
Table 8. Women Members of the Central Committee of the Communist Party of Czechoslovakia (in percent).

\begin{tabular}{lccc}
\hline Year & Total Members & Full Members & Candidate Members \\
\hline 1949 & 13.9 & 14.4 & 12.5 \\
1954 & 9.8 & 10.7 & 7.1 \\
1962 & 11.0 & 11.3 & 10.0 \\
1966 & 9.7 & 10.0 & 8.9 \\
1971 & 8.7 & 10.7 & 25.6 \\
1976 & 15.0 & 0 & \\
\hline
\end{tabular}

Sources: Compiled from information in Protokol 9. Sjezdu KSC (Prague, 1949); 10. $S^{\prime \prime} e z d$ Kommunisticheskoi partii Chekhoslovakii (Prague, 1954); 12. Sjezd Komunistické strany Ceskoslovenska (Prague, 1963); 13. Sjezd Komunistické strany Ceskoslovenska (Prague, 1966) ; Rudé právo, May 31, 1971, p. 2; 15. Zjazd KSĆ: Dokumenty a materialy (Bratislava, 1976).

deputies on the committees dealing with foreign affairs, constitutional and legal matters, and agriculture. ${ }^{30}$

A similar pattern is evident in women's representation in Communist Party elites. Women's representation in party bodies is lower than in government bodies at all levels, but it also decreases as the importance of the office rises. Women have been extremely rare in the top decision-making body of the party, the Presidium or Politburo, and have been underrepresented on the Central Committee of the Communist Party in relation to their proportion of party members. As table 8 indicates, women comprise a far smaller proportion of Central Committee members than of national legislators. They have been consistently better represented on the Central Committee of the Slovak Communist Party than of the CPCS as a whole, although this difference has not been great. ${ }^{31}$ Again, it is at the lower levels that women are best represented. They comprised 10 percent of members of regional and 13.5 percent of district party committees in 1955, and approximately 17 percent of regional and district committee members were women in 1960. Even at this level, however, they are noticeably absent from positions as First Secretaries or members of executive committees. ${ }^{32}$

In sum, women, although well represented in the symbolic elites, play a small role in effective decision-making bodies. The symbolic nature of women's representation at the elite level is further illustrated by the social background characteristics of women in both types of elites. Like their female counterparts in the West, Czech and Slovak women in political elites differ markedly from male members in previous political experience and social background. Studies of women in Western political elites indicate that they are generally of lower socioeconomic status and educational levels and also tend to have had less prior

30. Figures have been taken from information in U.S. Department of State, Bureau of Intelligence and Research, Directory of Caechoslovak Officials, 1965 (Washington, D.C., 1965), and Directory of Czechoslovak Officials, 1971 (Washington, D.C., 1971).

31. Women comprised 14.8 percent of the membership of the Central Committee of the Slovak Communist Party in 1962, 12.3 percent in 1966, and 12.8 percent in 1971 (taken from information in Zjazd Komunistickej strany Slovenska 13.-15. maja 1971 [Bratislava, 1971], pp. 201-4).

32. Chovanec, Zastupitelská soustava, pp. 126-37. 
political experience than their male counterparts. ${ }^{33}$ These differences, while they suggest that selection criteria are less stringent for women who aspire to elite positions, also limit the skills and degree of influence they exercise once they become members of the elite. ${ }^{34}$

The occupational composition of the Czechoslovak National Assembly elected in 1971 indicates that sex-related differences in occupation are also common in Czechoslovakia. Party and government officials constitute the largest single category of male deputies ( 32.9 percent), but only two of the ninety female deputies held such positions at the time of their election. Approximately 55 percent of all women legislators (compared with approximately 19 percent of all men) were workers. The extent to which women were drawn from lower level occupations is more fully evident in the proportion of deputies of each sex who were workers and farmers. Nearly three-fourths of all female deputies, but slightly less than one-third of all males, had these occupations. ${ }^{35}$

The occupations and degree of previous political experience of men and women members of the party elite also differ. Over one-third of all male full members of the Central Committee in 1971, for example, were full-time employees of the central party apparatus or held government positions at the time of their election. Most of the remaining men had long records of party experience, many at the central or regional level. Although five of the eight women who were full members had some degree of party experience, only one was a career party activist. The party experience of the other women full members was at the district or local level. It is also of interest that women comprised three of the five workers among the ninety-three members of the Central Committee for whom information on social background is available. ${ }^{36}$ The differences in social background characteristics indicate that women may play a doubly symbolic role in political elites. They appear to be recruited for elite roles not as a reward for lengthy party activism or because they possess specialized skills, but because they represent two ideologically important social categories. The "token" woman is a very real phenomenon in Czech and Slovak politics.

As in the case of Western elites, there is little direct evidence of the impact of differences in social backgrounds on the attitudes, political orientations, or policy preferences of men and women. Such differences do affect the tenure and turnover of women members, as the turnover rates and tenure of women members of the 1971 Central Committee illustrate. While the membership of the Central Committee as a whole changed radically in the period between the

33. Jennings and Thomas, "Men and Women in Party Elites," pp. 457-77; Ingunn Norderval Means, "Political Recruitment of Women in Norway," Western Political Quarterly, 25, no. 3 (September 1972) : 506-10; Edmond Constantini and Kenneth H. Craik, "Women as Politicians: The Social Background, Personality, and Political Careers of Female Party Leaders," Journal of Social Issues, 28, no. 2 (1972): 220; Charles S. Bullock, III and Patricia Lee Findley Heys, "Recruitment of Women for Congress: A Research Note," Western Political Quarterly, 25, no. 3 (September 1972) : 417-18.

34. Jennings and Thomas, "Men and Women in Party Elites," pp. 476, 480-84; Constantini and Craik, "Women as Politicians," pp. 227-31; Means, "Political Recruitment of Women in Norway," p. 516. 1971.

35. From information in "Poslanci Národního Shromáždění," Rudé právo, December 1,

36. From information found in "The New CPSC Central Committee," in Radio Free Europe Research, Czechoslovak Situation Report, no. 24, June 25, 1971. 
1966 and 1971 Party Congresses, the impact of such changes was particularly dramatic in the case of women members. Of the 1966 Central Committee members, one of the eleven women, as compared with approximately 25 percent of the men, was reelected to that body in 1971 . Only two of the eight women full members of the 1971 Central Committee, compared with over 50 percent of male full members, had been on the Central Committee previously. ${ }^{37}$ Given their small numbers, brief tenure, and lack of appropriate political skills and connections, women members of top party bodies can hardly be expected to wield much influence.

Many of the remaining inequalities in the position of women may be traced to the lack of change in the roles of both men and women in the family. Despite assumption of new roles in the economy, women continue to carry the traditionally female responsibility for caring for the home and family. Time-budget studies conducted on the basis of a representative sample of persons 15 years of age and older in 1967 indicate that employed women spend four hours and fifteen minutes a day on housework and child care, while males spend on the average one hour and fourteen minutes. ${ }^{38}$ The amount of time men and women spend on these activities varies somewhat according to educational and occupational level, but the differences are not great, and the main burden of work connected with the home and children remains with women at all educational levels and in all occupations. ${ }^{39}$

Traditional conceptions of the woman as guardian of the home and the man as the family's link to the outside world also influence the use of free time. Women's contacts outside the home tend to be confined to a smaller circle of close relatives and neighbors, while men tend to have more contacts with colleagues from work. The types of issues which men and women discuss with contacts outside the home also differ. Women's discussions focus on family and neighborhood affairs, while men are more likely to discuss cultural, sporting, and political issues. ${ }^{40}$

The persistence of traditional roles within the family poses both objective and subjective barriers to women's advancement outside the home. As a result of the unequal division of household responsibilities, women have appreciably less free time. ${ }^{41}$ The lack of free time is one of women's most common complaints, and the conflict between women's roles as economic producers and their roles

37. From information in 13. Sjezd Komunistické strany Ceskoslovenska (Prague, 1966), and Rudé právo, May 31, 1971.

38. Ernest Magdolen, Rodina, její společenský význam a misto v socialistickém zpuisobu života (Bratislava, 1973), p. 35. The difference between the sexes in time spent on housework is similar to that which exists in other socialist and Western countries. Time-budget studies conducted in 1969 indicate that men in the United States, for example, spent 1.1 hours and women 3.4 hours per day on housework, a difference of 2.3 hours (see V. D. Patrushev, "General Regularities and Features in the Use of the Time-Budget of the Employed Urban Population in Socialist and Capitalist Countries, Society and Leisure, 1974, no. 1, pp. 102-3 for more detail).

39. Magdolen, Spôsob żivota, appendix, table 1.

40. Magdolen, Rodina, pp. 63-64; Magdolen, Spôsob života, pp. 93-94.

41. Time-budget studies indicate that women have on the average 115 minutes of free time a day, men 190 minutes (Magdolen, Spôsob života, appendix, table 1). 
in the family is a frequently researched subject. The difficulty of carrying what has become known as a "dual burden" is confirmed by studies which indicate that most women do not feel they can perform both roles adequately. ${ }^{42}$ The strains these dual roles place on women in an economy with shortages of consumer goods, services, and household durables are evident in the comments women made in the late 1960 s, for example:

We were equal, happy, and joyful; but all around us, hundreds of women raced, just as we did, from nurseries to work, from work to nurseries, to shop, to go home, to change into a cook, then change again into a family pedagogue, who corrected the homework of her children, then immediately again into the loving, all-understanding wife of her weary husband. But then we also had to be qualified laundresses, model ironers, and when it was already very late at night, we might also be readers of the daily press. But we were already such, that [instead] we were happier to be qualified menders of the family laundry. ${ }^{43}$

The unchanging demands of home and children hinder women's professional advancement and are linked to their unwillingness to be more active politically. Studies of the qualification levels of women in industry conducted in the early 1960 s and 1970s indicate that women have less interest than men in raising their qualifications. As noted earlier, they are also less willing to accept responsible economic positions. Most women point to responsibilities connected with the home and family as the main reason for this lack of interest in improving their skills and accepting more demanding jobs. ${ }^{44}$

The traditional division of labor within the home also limits women's participation in politics. Given the difficulties most women have in performing their two essential roles, it is understandable that they would be hesitant to fill the free time available with political activity. This reluctance may be particularly great in socialist societies, where political involvement is especially time-consuming. Time constraints are particularly limiting for professional women. As in Western countries, there is a trade-off between the demands of a woman's profession and her public activity, given the constant obligations to home and family. Educated women employed in demanding professions appear to be less directly engaged in political activity than others. ${ }^{45}$ Time-budget studies indicate that time spent on improving qualifications and public activity increases for both sexes as educational levels rise, although at all educational levels men spend more time on both activities than women. If education is held constant, women employed in more demanding occupations spend somewhat less time on public activity, but twice as much time as other women workers on improving their qualifications. ${ }^{48}$ The

42. Numerous studies on the effects of the dual roles of women highlight these difficulties. See Bártová, "Žena a rodina," for summaries of several of these. Over 45 percent of women interviewed in Hora's 1971 study said they could not fulfill both roles satisfactorily; an additional 35 percent could do so only with difficulty (Hora, $Z a$ vy̌šsiu účast, p. 18).

43. Funkcionářka, 1968, no. 4, p. 10.

44. Jirí Blucha, "Kvalifikace žen ve strojírenství," Zprávy státñi populačni komise, 1966, no. 1, p. 32; Hora, Za vyššiu účast, pp. 15 and 27.

45. Constantini and Craik ("Women as Politicians") suggest that party activism may act as a compensatory outlet for women who do not have other means of self-expression.

46. Magdolen, Spôsob života, appendix, table 4. 
minimal amount of time professional women spend in political activity may in turn limit their professional advancement in a society in which a certain degree of activism in party and public organizations is required of persons who are employed in important positions.

Women's professional advancement and political participation is hindered in more subjective ways by the traditional conceptions of their roles in the home. Factory directors and other leaders identify women's domestic obligations as the main impediment to increasing the number of women in responsible positions, and they also see men as being better qualified for such positions because they have fewer responsibilities at home. ${ }^{47}$ Such views prevent many directors from considering women for leading posts, regardless of women's domestic situations or leadership potential. They also influence women's self-image and attitudes toward occupational and public life and limit their aspirations.

Given the unchanged roles of women in the home, it is difficult to foresee significant improvement in their status in other areas of life. As a Slovak sociologist has noted, women's continued responsibility for the care of children and the home means that equal opportunity for education and labor force participation does not lead to equal results. ${ }^{48}$

The establishment of a Communist political system in Czechoslovakia has not been accompanied by women's equality in that society. Despite marked changes in women's educational access and labor force participation, women are still excluded from decision-making posts and the exercise of authority in the economy and in politics. Many of the continued inequalities in wages, professional advancement, and share in political power may be traced to the persistence of traditional conceptions of women's roles and responsibilities in the family.

Given the formal commitment of the elites to female equality, how can this persistence be explained? Does the uneven pattern of change in women's roles reflect lack of elite commitment, popular resistance to change, or the difficulty of promoting change in certain areas? While the latter two factors have certainly played a role in determining women's status, the uneven pattern of change in female roles is primarily the result of differential elite commitment to promoting change in various areas of life.

Simply put, Communist elites have given lip service to the need for change in all areas of women's lives, but they have taken concrete action only in certain areas. In Czechoslovakia, as in the Soviet Union, elite policy toward women has been determined not by an abstract commitment to female equality, but by the more pragmatic consideration of the utility of various changes in women's roles for the attainment of other, higher priority elite goals. ${ }^{49}$

In the early post-World War II period, policy toward women was guided by the need to ensure an educated and expanded labor force in order to fulfill economic plans and growth projections. Ideological emphasis on economic inde-

47. Jolana Jančovičová, "Problematiky ženy v lekarském povolani na Slovensku," Sociólogia, 6, no. 5 (197,4) : 451-59; Hora, $Z a$ vyššiu účast, pp. 15-27.

48. Drahoslava Fukalová, Żena a práce v naši společnosti (Prague, 1969), p. 17.

49. See Gail Warshofsky Lapidus, Women in Soviet Society: Equality, Development, and Social Change (Berkeley, 1978), for an analysis of elite policy toward women in the Soviet Union. 
pendence as a precondition for female emancipation coincided with economic necessity, and women were encouraged to improve their skills and enter the labor force. The elites also attempted to ensure women's allegiance to the new political order and encouraged women to advance professionally. However, women were clearly expected to continue to perform their traditional roles in addition to assuming new ones. The ideal woman was one who could combine her multiple roles successfully. In the years immediately following World War II, the difficulties women encountered in living up to this model were sometimes acknowledged by party officials and leaders of the women's organizations. Little concrete help in the form of child-care facilities or improved services for working women was forthcoming, however. Increasingly, women's problems were simply overlooked. In the early 1950s, the "woman question" was declared solved, and women became a "nonissue" politically. The women's sections of the party were disbanded, and the women's organizations transformed from groups with mass membership to subcommittees of the local government serving largely to mobilize women to perform community services. ${ }^{50}$

Since the mid-1960s, policy toward women has been determined largely by its impact on the birth rate. Beginning in the early 1960s, Czechoslovakia experienced a sharp decline in its birth rate. Although such a decline is common to most countries which have become more developed economically, the decline in Czechoslovakia was particularly severe and reflected the impact of certain features of the post-World War II strategy of economic development and investment, including housing shortages, a low level of services, and an extremely high rate of employment among women of childbearing age. ${ }^{51}$ Concern over the falling birth rate led to investigation of its causes and to the adoption of measures, such as increased maternity leave and improved child-care allowances, designed to help women perform their maternal functions. It also led eventually to a reconsideration of the situation of women under socialism. While the original studies focused on women's childbearing roles, the connection between those roles and women's activities in other areas of life led to a reopening of the discussion of the woman question in general. ${ }^{52}$

The debate concerning the demographic situation and measures adopted to improve it illustrate several interesting features of the elite's approach to women's issues in Czechoslovakia. As in the past, policy toward women continues to be determined largely by consideration of other goals. The policies which have been adopted to improve the situation of women are those which will have a

50. For a comprehensive analysis of elite policy toward women in the early post-World War II period, see Sharon Wolchik, "Socialism and Women in Czechoslovakia: Mobilization or Liberation?," paper presented at the 1978 annual meeting of the Midwest Slavic Association, Bloomington, Indiana, April 14-16, 1978.

51. Live births per 1,000 population averaged 22.4 from 1945 to $1949 ; 22.0$ from 1950 to 1954 ; 18.5 from 1955 to 1959 ; and 16.3 from 1960 to 1964. In 1965, there were 16.4 per 1,000 and by 1966, 15.6. "Přehled demografického vývoje a populační politiky evropských socialistických států," Zprávy státní populačni komise, 1969, no. 4, p. 5.

52. The earliest studies on the position of women in socialist society were conducted by demographers. See Vladimír Srb, Demografická príručka (Prague, 1967), for summaries of these studies. After sociology was reestablished as an academic discipline in the early 1960s, sociologists also began to conduct research on this theme. For reports of seminars and research on women's situation, see Bártová, "Žena a rodina," and Eva Bártová, "Postáveni žen v socialistickém společnosti," Zprávy státni populačni komise, 1965, no. 4, pp. 32-46. 
positive influence on the birth rate. Members of the political elite occasionally discuss the need for a more equal division of labor within the home, but the measures designed to improve the birth rate presume that women will continue to have the major responsibility for care of the home and family. While these measures and the general reemphasis on the importance of women's roles as mothers have undoubtedly relieved some of the most pressing problems for individual women, their impact on female equality is problematic, for they reinforce the traditional division of labor within the home.

The instrumental orientation of the elite toward women in turn reflects certain aspects of Marxist-Leninist theory which vitiate, to a certain extent, formal commitment to female equality. Except for a brief period in the 1960s, Czech and Slovak leaders have relied on a framework of analysis of women's issues which traces the inequality of women to basically economic roots.

Exploitation of women is linked to dependency within the family and to the perversion of family relations by the corrupting influence of private property. Once this influence is removed, that is, when a socialist society has been established, relations between the sexes are expected to partake of the change in human relations in general. Reliance on this formulation, most systematically set out by Engels, led to repeated emphasis that female equality was possible only under socialism. Engels's emphasis of the economic roots of female inequality also led to the notion that the advance toward socialism in and of itself would solve remaining problems in the position of women. Given such a perspective, there was no need to consider women's interests apart from those of social development in general..$^{53}$

The impact of this analysis of the causes of female inequality has been exacerbated by the organizational principles of socialist society. Because social relations under socialism are thought to be basically harmonious, there is little recognition of the possibility for continued conflict between the interests of particular groups and those of society as a whole once a socialist system has been established. Thus, in normal political times, groups do not have the right to organize independently to articulate and advance their own interests or adopt an advocacy position vis-à-vis the party or government.

Opportunities for action on their own behalf appear to be important for all disadvantaged social groups. Marx and Lenin saw the need for such activity clearly in the case of workers, and it has been validated by the experience of many ethnic and racial minority groups. Such opportunities are particularly crucial for women. As has been argued in the case of American blacks, women are prevented from participation in certain types of activities by an ascribed status which implies a particular set of duties and roles. Change in women's status depends, in the final analysis, on a redefinition of these roles. This redefinition, which involves rejection of old values and reevaluation of possibilities by

53. See Alfred G. Meyer, "Marxism and the Women's Movement," in Dorothy Atkinson, Alexander Dallin, and Gail Warshofsky Lapidus, eds., Women in Russia (Stanford, Calif., 1977), pp. 85-113, for an analysis of the writings of Marx and Engels on women. Hilda Scott also discusses the influence of this framework of analysis in Hilda Scott, Does Socialism Liberate Women?: Experiences From Eastern Europe (Boston, 1974), chapters 9 and 10. 
individuals, is facilitated by interaction with others who are undergoing the same process. ${ }^{64}$

The importance of opportunites for independent organization became evident in Czechoslovakia in the late 1960s. Prior to that time, renewed discussion of women's issues was confined largely to specialist elites, such as demographers and sociologists, who used the results of their empirical research to assess women's status more realistically and called for more attention to women's problems. In the context of the unusual political conditions of the reform period, discussion of women's issues spread to broader groups of people. As in many areas of life, the more open political and intellectual climate led to the ventilation of long unexpressed feelings about women's position. Debate over unresolved problems filled the pages of women's magazines, and women's issues were given more attention in the general press. Women pointed out the problems which had resulted from a decade's neglect of women's issues and called on central authorities to take concrete action to improve their situation. These activities were encouraged by the leaders of the women's organization, which was reestablished in late 1967. In the context of the reform period, these organizations, like other mass organizations, began to function as interest groups in the Western sense of the term. ${ }^{55}$ Allied with certain elements of the reform leadership, leaders of the women's organization bargained with party and government leaders and defended women's interests. They also attempted to involve large groups of women in proposing solutions to women's problems and worked to increase the authority of the organization. Finally, leaders of the women's organization questioned the validity of earlier formulations concerning the nature and causes of female inequality and argued for the elaboration of more adequate theoretical perspectives. With the end of the reform period, these organizations reverted to their former role of mobilizing women to fulfill regime determined objectives. Some of the activities begun during this time continue, but the process of redefinition and advocacy of women's issues has largely ended. ${ }^{\mathbf{5 6}}$

In sum, the experiences of Czech and Slovak women indicate that there are important limitations to the Marxist-Leninist method of emancipating women.

54. For a discussion of the influence of these factors in the case of blacks and women in the United States, see William H. Chafe, Women and Equality: Changing Patterns in American Culture (New York, 1977).

55. See H. Gordon Skilling, Czechoslovakia's Interrupted Revolution (Princeton, 1976), for an analysis of the actions of various groups and organizations during and immediately after the reform period.

56. The analyses and objectives of women's leaders during this period were by no means those of radical feminists. Reacting to the problems created by previous emphasis on women's roles as workers, leaders of the women's organizations advocated renewed attention to women's maternal roles and called for measures to ease the conflict between women's roles. Although many of the leaders of the women's organization continued to be guided by an assimilationist view of sex roles, they did challenge the prevailing analysis of the causes of female inequality and attempted to involve large groups of women in thinking about and discussing women's issues. Given enough time, this process of discussion, interaction, and reconsideration may have led to the adoption of new perspectives on role change as well as on women's issues. For an analysis of the change in elite policy and the activities of the women's organizations in the mid to late 1960s, see Wolchik, "Politics, Ideology, and Equality," chapters 6 and 7. 
Those changes which have occurred in women's status have come about largely because of either economic or demographic considerations. The elites have also encouraged women to advance in their professions and to be more active politically, but they have not created the preconditions which would allow women to do this, either in terms of committing material resources to improve services and child-care facilities or by challenging the traditional division of labor within the home.

Given the lack of elite commitment to promoting change in these areas, opportunities for independent action by women are crucial if any change is to occur. Public opinion surveys indicate that many women in Czechoslovakia, particularly well-educated women, are aware of the inconsistencies in their status and dissatisfied with the current situation. ${ }^{57}$ In the late 1960 s, women were able to articulate their dissatisfaction. In normal political times, however, the terms in which women's problems are analyzed and the lack of opportunity to organize independently prevent the translation of the individual dissatisfaction of women into effective political action.

57. See Wynnyczuk, "Venkovská žena"; Bártová, "Postoje k problému"; and Magdolen, Spôsob života, for illustrations of women's dissatisfactions and perceptions concerning equality. 